\title{
Common Phobias among Egyptian Primary Schoolchildren: An Emergency Trigger for Panic Disorder due to Corona Pandemic
}

\author{
A. M. Metwally ${ }^{1}$, Marwa M. El-Sonbaty ${ }^{2,3}$, Ghada A. Abdel-Latif ${ }^{1 *}$, Lobna A. El-Etreby ${ }^{1}$, Hanan Elsayed $^{4}$, Eman Elsheshtawy ${ }^{4}$, \\ Amal Elsaeid ${ }^{5}$, Nihad A. Ibrahim ${ }^{1}$ \\ ${ }^{1}$ Community Medicine Research Department, Medical Research Division, National Research Centre, (Affiliation ID: 60014618), \\ Dokki, Cairo, Egypt; ${ }^{2}$ Child Health Department, Medical Research Division, National Research Centre, (Affiliation ID: 60014618), \\ Dokki, Cairo, Egypt; ${ }^{3}$ Department of Pediatrics, College of Medicine, Taibah University, Madinah, Saudi Arabia; ${ }^{4}$ Department \\ of Psychiatry, Mansoura University, Mansoura, Egypt; ${ }^{5}$ Department of Child with Special Needs, Medical Research Division, \\ National Research Centre, (Affiliation ID: 60014618)
}

Edited by: Mirko Spirosk Citation: Metwally AM, El-Sonbaty MM, Abdel-Latif GA, El-Etreby LA, Elsayed H, Elsheshtawy E, Elsaeid A, Ibrahim NA. Common Phobias among Egyptian Primar Schoolchildren: An Emergency Trigger for Panic Disorde due to Corona Pandemic. Open Access Maced J Med Sci https://doi.org/10.3889/oamims.2020.4766 Keywords: Common phobias; Primary school; Children; Panic disorder; Corona pandemic *Correspondence: Dr. Ghada A. Abdel-Latif, Community Medicine Research Department, Medicine Research Division, National Research Centre, 12411, El Behoos Street, Doki, Giza, Egypt. Tel.: + 01001481775 E-mail: dr.ghada237@gmail.com Received: 10-Apr-2020 Revised: 22-Apr-2020 Copyright: ๑ 2020 A. M. Metwally, Marwa M. El-Sonbaty, Ghada A. Abdel-Latif, Lobna A. El-Etreby, Hanan Elsayed, Eman Elsheshtawy, Amal Elsaeid, Nihad A. Ibrahim pported by the Scientific Foundation SPIROSKI, Skopje Republic of Macedonia Competing Interests: The authors have declared that no
competing interests exist Competing Interests: The authors have declared that no
competing interests exist

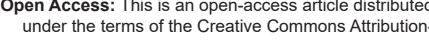
NonCommercial 4.0 International License (CC BY-NC 4.0)

\begin{abstract}
BACKGROUND: In the wake of the adverse situation we are currently facing globally due to the coronavirus pandemic outbreak, it is normal to feel stressed, confused, and scared but what is abnormal is to turn this to panic. Phobias are more pronounced than fears. They develop when a person has an exaggerated or unrealistic sense of danger that may be evolved to experience panic attacks.

AIM: Our objective was to identify the prevalence of most common phobias as well as panic disorder (PD) due to the coronavirus pandemic among Egyptian primary schoolchildren and their determinants.

METHODS: A cross-sectional study was conducted among 2015 schoolchildren from 3 to 6 grades in three governorates of Egypt. Seven types of phobias were investigated: Agoraphobia, phobias from darkness, animal, untreatable illness (mainly coronavirus), insects, height, and social phobia. The child's self-reported PD symptoms were assessed using DSM-IV with psychiatric diagnoses.

RESULTS: Almost two-thirds of the surveyed primary schoolchildren have phobias of the low score $(<9)$ versus one-third who had high phobias score $(61 . \%$ vs. $35 \%$, respectively) with highly significant difference $(p<0.001)$ The most prevalent phobias were from heights $(66.5 \%)$ followed by darkness $(60.0 \%)$. The important predictors of phobias were: Being a male child, living in an urban area, and studying at governmental school at fifth or sixth-grade residence. The prevalence of PD due to the corona epidemic is very high, it is reported by almost half of the surveyed primary schoolchildren. Fear of losing any of their family members, especially grandparents, was reported to be the highest PD symptom (97\%).
\end{abstract}

CONCLUSION: Phobia from heights and darkness was the most common. The prevalence of PD due to the coronavirus epidemic is reported to be very high. Calming down children who might be experienced with a phobia that is triggering their PD is recommended.

\section{Introduction}

A phobia is defined by being a debilitating, massive, and persistent fear. It is triggered by the presence of a situation, animal, heights, illness, etc. If a phobia becomes very severe, it causes restricting of the day-to-day life and a lot of distress. As well as, the person will avoid the thing that causing phobia [1], [2].

To consider phobia in children, the identified fear must last at least 6 months. Types of common phobias seen in children include specific phobia (e.g., fear from darkness, animal, insect, or heights), agoraphobia (e.g., fear of crowded places or narrow places), social phobia (as phobia when entering a place where people are gathered and talking for fear of embarrassing yourself and being humiliated in public), and medical phobia (afraid of illness) [1], [2], [3], [4].
Phobia is common in all ages, with $25 \%$ of children and adolescents suffering from phobia during their lifetime, making it one of the most prevalent and chronic psychological disorders [2].

Specific phobia is considered one of the most common phobias. Recent studies show that the lifetime prevalence of specific phobias around the world ranges from $3 \%$ to $15 \%$ and the most common types are heights and animals. These studies confirm the high prevalence of specific phobias in the general population, especially in children.7-8. The National Institute of Mental Health estimates approximately $7-9 \%$ of children have been estimated to have a specific phobia [5], [6], [7], [8]. Moreover, younger individuals showed the highest rates of social phobia. It usually first appears at age 8 years [9], [10].

The prevalence rates and types of phobia in children differ in nature due to different cultural and 
ethnic groups. Traditions, values, and beliefs may play a role [5], [11].

Phobia might act as a triggering factor for Panic. Recent researches indicated that panic disorder (PD) has been documented not only among adolescents but also many primary school-aged children experienced this disorder nowadays [12], [13], [14].

Coronavirus (COVID-19) is a lower respiratory tract infection and it is considered by the World Health Organization as a pandemic disease because it causes more than 430,000 cases and almost 20,000 deaths worldwide [15], [16].

In the wake of the adverse situation we are currently facing globally due to the COVID-19 outbreak; the whole nations are confronted with a pandemic for which all government agencies are doing their best to control. Meanwhile, to fight this pandemic efficiently, the majority of nations have reinstated a work-from-home policy to help in flattening the COVID transmission curve. All parents are working under extreme pressure at this time that is also reflected in their children. To enable parents to work optimally from home, it is necessary to create an enabling environment that is free from any phobia or panic. This is also necessitated to calm down children who might be experienced with a phobia that is triggering their PD.

To assist in these potential crisis moments and achieve our target with resilience and compassion, we assessed the prevalence of phobia among primary school-aged children as a trigger for PD due to Corona Pandemic. We assessed the prevalence of phobia among primary school-aged children as a trigger for $\mathrm{PD}$ due to the corona pandemic. When it comes to $\mathrm{PD}$ due to the coronavirus epidemic, it is essential to measure PD among children. The experienced panic illness usually accompanied by decreased resistance and more susceptibility to diseases [17], [18], [19].

The aim of this study was to identify the prevalence of most common phobias among the studied Egyptian primary school-aged children and determine the prevalence of different types of phobia and their determinants according to certain demographic characteristics. The study also will focus on the prevalence of PD due to the coronavirus pandemic and detect the dominance of its symptoms.

\section{Methods}

\section{Study design and study setting}

The study was a cross-sectional that was conducted in three governorates, one representing Lower Egypt (Behara governorate), one representing the Coastal region (Damietta governorate), and one representing Upper Egypt (AI Fayoum governorate).
Sampling frame and sampling unit; three sampling frames were chosen: The first sampling frame used was based on stratification of the served rural governorates into three strata representing rural Lower Egypt, Coastal region, and Upper Egypt governorates. The second sampling frame was based on a comprehensive list of the governorates as per regions. The third sampling frame was the stratification of listing the units to be sampled (governmental primary schoolchildren). For the third sampling frame, a logical order was used for schools and then a cluster of schools was chosen with probability proportion to size from that listing. This ensured that the units were evenly distributed within the listing and avoided the possibility that, due to chance, one type of school ends up being under-represented.

Governorates that matched the inclusion criteria and randomly selected were Al Fayoum, Damietta, and Behara governorates representing Lower Egypt, Coastal region, and Upper Egypt governorates, respectively.

\section{Sample size and sampling technique}

Confidence intervals for one proportion Numeric results for two-sided confidence intervals for one proportion.

\begin{tabular}{|c|c|c|c|c|c|c|c|}
\hline \multicolumn{3}{|c|}{$\begin{array}{l}\text { Confidence } \\
\text { (Clopper-Pearson). }\end{array}$} & \multicolumn{2}{|c|}{ interval } & \multicolumn{2}{|c|}{ formula: } & \multirow[t]{2}{*}{ Exact } \\
\hline Sample & & & & & & & \\
\hline $\begin{array}{l}\text { Confidence } \\
\text { level } \\
0.970\end{array}$ & $\begin{array}{l}\begin{array}{l}\text { Size } \\
(\mathrm{n})\end{array} \\
1921\end{array}$ & $\begin{array}{l}\text { Target } \\
\text { width } \\
0.050\end{array}$ & $\begin{array}{l}\begin{array}{l}\text { Actual } \\
\text { width }\end{array} \\
0.050\end{array}$ & $\begin{array}{l}\text { Proportion } \\
\text { (p) } \\
0.500\end{array}$ & $\begin{array}{l}\text { Lower } \\
\text { limit } \\
0.475\end{array}$ & $\begin{array}{l}\text { Upper } \\
\text { limit } \\
0.525\end{array}$ & $\begin{array}{l}\text { Width if } \\
p=0.5 \\
0.050\end{array}$ \\
\hline
\end{tabular}

\section{Summary statements}

A sample size of 1921 produces a two-sided $97 \%$ confidence interval with a width equal to 0.050 when the sample proportion is 0.500 . This sample is the minimum sample to ensure the accuracy of the results with.05 margin of error and 97\% confidence [20].

\section{Study population}

The choice of subjects was in the form of clusters (4 clusters/each school); each cluster was formed from 17 students from each grade with a total of 68 children/each primary schoolchildren. The actual total number of the randomly surveyed schools was 30 schools distributed along 16 districts within three governorates with average 1-3 schools/district and 10-12 schools/each of the selected governorates according to the number of schools per district. The total number of children was rounded to 2040. Of the expected 2040 children, 2015, children completed the questionnaire. These schoolchildren were in the age group 8-12 years, studying at primary levels in governmental and private schools in some rural and urban areas of three governorates of Egypt. 


\section{Inclusion criteria}

Boys and girls in the primary schools from grade 3 to grade 6 . The primary schoolchildren are aged 8-12 years so that they could express their feelings properly. The study included both private and governmental schools as well as schools in rural and urban areas.

\section{Exclusion criteria}

Students proved to have any mental disorder, visual or auditory impairment, or chronic disease were excluded from the study.

\section{Data collection types and tools}

The questionnaire was designed and distributed to the parents of the studied schoolchildren studying at primary levels and living in both urban and rural areas of Egypt. The designed questionnaire was completed by the primary schoolchildren.

Seven types of phobias were investigated: Agoraphobia, phobia from darkness, phobia from animal, phobia from untreatable illness (mainly coronavirus), phobia from insect, phobia from height, and social phobia. The questionnaire consisted of some sociodemographic data (age, gender, residence, school type, and school level) and 20 questions related to different types of phobia. Students' parents were asked to answer the questions by indicating "yes" or "no." Questions evaluate the levels of phobia were scored from zero to $\geq 10$ where 0 means no phobia, 1-9 means a low level of phobia, however, the score of a high level of phobia ranges from 10 to more.

Children completed self-report rating scale [21].

Two child psychiatrists made psychiatric diagnoses through a systematic review of the symptoms.

DSM-IV panic symptoms were used for the child self-reported PD symptoms.

\section{Data management analysis}

The collected data were revised, coded, entered, and verified with proofreading data, where one researcher checked the data entered against the original document. Data analysis was done using Statistical Package for the Social Science 18 for windows. Descriptive statistics in the form of frequency and percentage were used for data summarization. Diagrams and figures were used to illustrate the other simple information. Qualitative data were presented in frequencies and percentages. Chi-square test was used for measuring differences; meanwhile, odds ratio and 95\% confidence interval were computed to assess the degree of association. The analysis was also done using $\mathrm{Z}$ test between two proportions [22]. Multivariate logistic analysis was done to predict risk factors significantly affecting phobia. $p<0.05$ was considered significant and $p<0.001$ was considered highly significant.

\section{Results}

Of 2015 studied schoolchildren in the age group 8-12 years, 52\% were female. The majority of the sample was studying at primary levels in private schools and was from rural areas of Egypt $(61.3 \%$ and $62.5 \%$, respectively). About one-third of the participants were studying in primary five $(30.3 \%)$, around onequarter of them were studying in primary three and another was studying in primary six ( $24 \%$ both), and $21.5 \%$ were studying in primary four.

Table 1 reveals the distribution of the most common phobias among the studied schoolchildren. Feeling of falling down from high places $(66.5 \%)$, phobia from dark places $(60.0 \%)$, phobia from going bathroom when it is dark $(57.1 \%)$, and phobia from untreatable illness (44.2\%) were the most common phobias found among the studied schoolchildren. Other types of phobias such as phobia when entering a place where people are gathered and talking (19.4\%) were found less commonly. The table also shows that low and high scores of phobia accounted for $60.9 \%$ and $35.2 \%$, respectively, with a highly significant difference and there is a highly significant difference between certain types of phobia $(p<0.001)$. More than $5 \%$ of the studied schoolchildren had from 5 to 12 types of phobia (Figure 1).

Table 1: Distribution of different types of phobia among the studied schoolchildren

\begin{tabular}{|c|c|c|}
\hline Type of phobia & $\begin{array}{l}\text { Total } n=2015 \\
n(\%)\end{array}$ & $p$-value \\
\hline \multicolumn{3}{|l|}{ Total score of phobia } \\
\hline No $(0)$ & $79(3.9)$ & $<0.001$ \\
\hline Low 1-9 & $1227(60.9)^{*}$ & \\
\hline High 10 or more & $709(35.2)^{*}$ & \\
\hline \multicolumn{3}{|l|}{ Agoraphobia } \\
\hline Phobia from narrow places & $714(35.4)$ & $<0.001$ \\
\hline Phobia from train or bus even they are not crowded & $545(27.0)^{*}$ & \\
\hline Phobia from crowded places & $752(37.3)^{*}$ & \\
\hline \multicolumn{3}{|l|}{ Phobia from darkness } \\
\hline Phobia from dark places while he is in & $1208(60.0)$ & $<0.001$ \\
\hline Imagine that somebody is talking to him while he is in darkness & $750(37.2)$ & \\
\hline Phobia from going alone to bed at night & $658(32.7)^{*}$ & \\
\hline Feeling shudder when he is in darkness & $984(48.8)$ & \\
\hline Imagine in darkness that somebody on the wall & $930(46.2)$ & \\
\hline Phobia from sitting in dark room & $1044(51.8)$ & \\
\hline $\begin{array}{l}\text { Phobia from going bathroom when it is dark } \\
\text { Phobia from animal }\end{array}$ & $1151(57.1)^{*}$ & \\
\hline Feeling dizzy and shudder when he sees a dog or cat & $572(28.4)^{*}$ & $<0.001$ \\
\hline Runaway and be tachycardia when seeing a dog or cat & $790(39.2)$ & \\
\hline Phobia from rats and be tachycardia on seeing a rat & $1031(51.2)^{*}$ & \\
\hline Phobia from snacks even if he saw them in TV or pictures & $893(44.3)$ & \\
\hline Phobia from untreatable illness (like corona) & $890(44.2 \%)$ & \\
\hline \multicolumn{3}{|l|}{ Phobia from insect } \\
\hline $\begin{array}{l}\text { Phobia from cockroach and become tachycardia on viewing a } \\
\text { cockroach }\end{array}$ & $690(34.2)$ & \\
\hline \multicolumn{3}{|l|}{ Phobia from height } \\
\hline Phobia from heights & $1034(51.3)$ & $<0.001$ \\
\hline $\begin{array}{l}\text { Feeling that he will fall down while he is in high places } \\
\text { Social phobia }\end{array}$ & $1340(66.5)$ & \\
\hline $\begin{array}{l}\text { Social phobia } \\
\text { Phobia from something or people he knows they are harmless }\end{array}$ & $514(25.5)$ & $<0.001$ \\
\hline $\begin{array}{l}\text { Phobia when entering place where people are gathered and } \\
\text { talking }\end{array}$ & $390(19.4)$ & \\
\hline
\end{tabular}




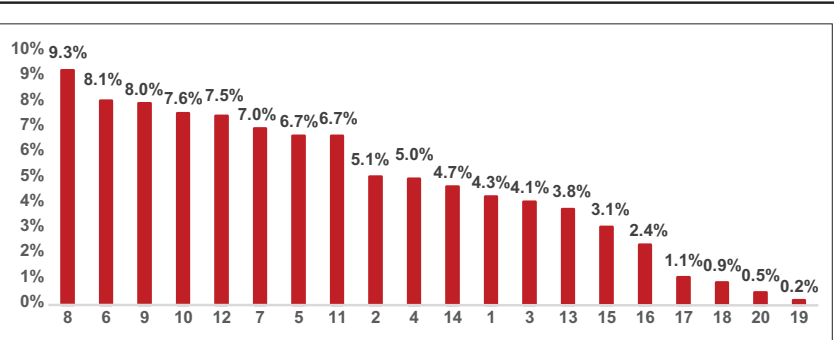

Figure 1: Percent distribution of different no. of phobias among the studied schoolchildren

The low score of phobia was more among the studied female schoolchildren $(63.5 \%)$, while the high score of phobia was more among the studied male schoolchildren (71.8\%). As regards low versus high scores of phobia, males were 4.4 times with highly significant $(p<0.001)$. There is a highly significant difference between rural and urban areas regarding no phobia versus high scores of phobia with odds ratio $3.5(95 \%$ Cl 2.1-5.7). Governmental schools were almost two times likely than private schools regarding low versus high scores of phobia with a highly significant difference $(p<0.001)$. Fifth graders scored higher than other graders, for low scores versus high scores of phobia with highly significant difference $(p<0.001)$ Table 2.

Table 2: Prevalence of phobia among the studied schoolchildren according to certain characteristics

\begin{tabular}{|c|c|c|c|c|}
\hline \multirow[t]{2}{*}{ Variable } & \multicolumn{4}{|l|}{ Phobia } \\
\hline & $\begin{array}{l}\text { Total } \\
n=2015\end{array}$ & $\begin{array}{l}\text { No }(0) \\
(n=79) n(\%)\end{array}$ & $\begin{array}{l}\text { Low }(1-9) \\
(n=1227) n(\%)\end{array}$ & $\begin{array}{l}\text { High }(10 \text { or more }) \\
(\mathrm{n}=709) \mathrm{n}(\%)\end{array}$ \\
\hline \multicolumn{5}{|c|}{ 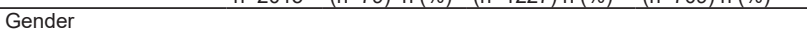 } \\
\hline Males & 967 & $10(12.7)$ & $448(36.5)$ & $509(71.8)$ \\
\hline Females ${ }^{\circledR}$ & 1048 & 69 (87.3) & 779 (63.5) & $200(28.2)$ \\
\hline \multicolumn{5}{|c|}{$\begin{array}{l}\text { OR }(\mathrm{Cl}) \text { between: No versus low=4.0 }(2.0-7.8)^{* \star} \text {, no versus high=17.6 }(8.9-34.8)^{\star \star} \text {, low } \\
\text { versus high=4.4 }(3.6-5.4)^{\star *}\end{array}$} \\
\hline \multicolumn{5}{|l|}{ Residence } \\
\hline Rural & 1259 & $28(35.4)$ & 765 (62.3) & $466(65.7)$ \\
\hline Urban $^{\circledast}$ & 756 & 51 (64.6) & $462(37.7)$ & $243(34.3)$ \\
\hline \multicolumn{5}{|c|}{$\begin{array}{l}\mathrm{OR}(\mathrm{Cl}) \text { between: No versus low=3.0 }(1.9-4.9)^{* *} \text {, no versus high=3.5 }(2.1-5.7)^{* *} \text {, low } \\
\text { versus high=1.2 }(1.0-1.4)\end{array}$} \\
\hline \multicolumn{5}{|l|}{ Type of school } \\
\hline Governmental & 780 & $17(21.5)$ & $425(34.6)$ & $338(47.7)$ \\
\hline Private $^{\circledast}$ & 1235 & 62 (78.5) & $802(65.4)$ & $371(52.3)$ \\
\hline \multicolumn{5}{|c|}{$\begin{array}{l}\text { OR }(\mathrm{Cl}) \text { between: No versus low=1.9 }(1.1-3.3)^{\star} \text {, no versus high=3.3 }(1.9-5.8)^{\star *} \text {, low } \\
\text { versus high=1.7 }(1.4-2.1)^{\star *}\end{array}$} \\
\hline \multicolumn{5}{|c|}{ School level/grade ${ }^{\star \star}$} \\
\hline Primary three & 483 & 27 (34.2) & $309(25.2)$ & $147(20.7)$ \\
\hline Primary four & 434 & 11 (13.9) & $264(21.5)$ & $159(22.4)$ \\
\hline Primary five & 611 & $30(38.0)$ & $371(30.2)$ & $210(29.7)$ \\
\hline Primary six & 487 & $11(13.9)$ & $283(23.1)$ & $193(27.2)$ \\
\hline
\end{tabular}

Table 3 illustrates the prevalence of different types of phobia among the studied schoolchildren according to certain characteristics. Prevalence of different types of phobia was more frequent in males than females with significant differences (agoraphobia $[p=0.008]$, phobia from darkness [ $p<0.001]$, animal phobia $[p=0.035]$ ). The frequency of different types of phobia was increased in rural areas than urban areas with significant difference (agoraphobia [ $p<0.001$ ], phobia from darkness $[p=0.043]$, animal phobia $[p<0.001])$. In addition, private schools demonstrated higher percent than governmental schools in almost all types of phobia with significant difference (phobia from darkness $[p=0.029]$, animal phobia $[p=0.001])$. The studied fifth graders (about one third) show the highest percentage for almost all types of phobia, whereas phobia from untreatable illness was more common in third and fourth grades students $(27.6 \%$ and $27.0 \%$, respectively).

Figure 2 with regard to PD symptoms due to coronavirus pandemic, somatic symptoms were not common; the most common somatic complaints were in order: Shortness of breath of children $(40 \%)$, chest pain, palpitations, nausea, trembling, sweating, and choking. Meanwhile, fear of losing family members was the most common (97\%), then the fear of the unknown consequences of the corona (78\%) and fear of dying $(68 \%)$ with a highly significant difference $(p<0.001)$.

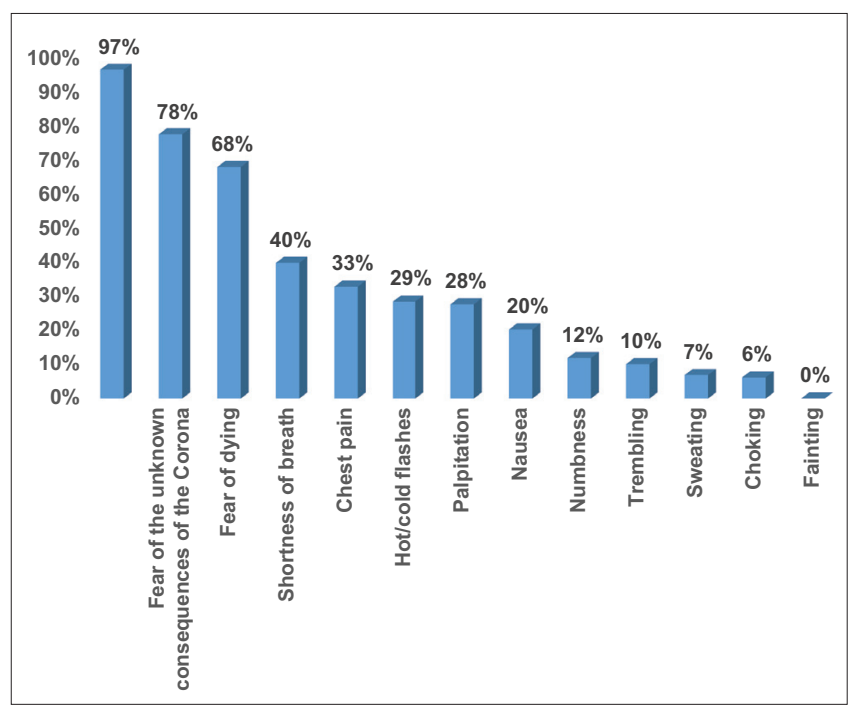

Figure 2: Prevalence of panic disorder's symptoms from catching coronavirus among the studied schoolchildren according to certain characteristics, $p<0.001$

Table 4 presents the logistic regression analysis for investigating factors affecting phobia among studied schoolchildren. It was carried out using a type of school, residence, gender, and school level/grade in the model. It revealed that male studied schoolchildren, urban areas, and governmental schools were highly significant predicting factors for phobia regarding low score of phobia versus high score of phobia, no phobia versus high scores of phobia, and no phobia versus low scores of phobia, $p<0.001$.

\section{Discussion}

Phobias are the most common anxiety disorder. It is characterized by the overwhelming and constant fear of specific objects or situations that present little or no real threat causing distress and impairment to the child's life [11], [23], [24]. If phobias are not treated and continue into adulthood, they will become chronic, causing a marked reduction in 
Table 3: Prevalence of agoraphobia, phobia from darkness, animal, illness, insect, height, and social phobia among the studied schoolchildren according to certain characteristics

\begin{tabular}{|c|c|c|c|c|c|c|c|c|c|c|}
\hline \multirow[t]{2}{*}{ Variable } & \multicolumn{2}{|l|}{ Gender } & \multicolumn{2}{|l|}{ Residence } & \multicolumn{2}{|l|}{ Type of School } & \multicolumn{4}{|c|}{ School level/primary grade } \\
\hline & Males & Females & Rural & Urban & Govern-mental & Private & Three & Four & Five & Six \\
\hline Phobia from narrow places $n=714$ & $445(62.3)$ & $269(37.7)$ & $522(73.1)$ & $192(26.9)$ & $318(44.5)$ & $396(55.5)$ & $160(22.4)$ & $155(21.7)$ & $223(31.2)$ & $176(24.6)$ \\
\hline $\begin{array}{l}\text { Phobia from train or bus even they are not } \\
\text { crowded } n=545\end{array}$ & $294(53.9)$ & $251(46.1)$ & $387(71.0)$ & $158(29.0)$ & $228(41.8)$ & $317(58.2)$ & $133(24.4)$ & $130(23.9)$ & $164(30.1)$ & $118(21.7)$ \\
\hline $\begin{array}{l}\text { Phobia from crowded places } n=752 \\
p \text {-value }\end{array}$ & $\begin{array}{l}453(60.2) \\
0.008\end{array}$ & $299(39.8)$ & $\begin{array}{l}482(64.1) \\
<0.001\end{array}$ & $270(35.9)$ & $\begin{array}{l}345(45.9) \\
0.347\end{array}$ & $407(54.1)$ & $\begin{array}{l}165(21.9) \\
0.744\end{array}$ & $172(22.9)$ & $245(32.6)$ & $170(22.6)$ \\
\hline $\begin{array}{l}\text { Phobia from dark places while he is in } \\
n=1208\end{array}$ & $743(61.5)$ & $465(38.5)$ & $737(61.0)$ & $471(39.0)$ & $508(42.1)$ & $700(57.9)$ & $255(21.1)$ & $242(20.0)$ & $380(31.5)$ & $331(27.4)$ \\
\hline $\begin{array}{l}\text { Imagine that somebody is talking to him } \\
\text { while he is in darkness } n=750\end{array}$ & $425(56.7)$ & $325(43.3)$ & $468(62.4)$ & $282(37.6)$ & $369(49.2)$ & $381(50.8)$ & $168(22.4)$ & $127(16.9)$ & $250(33.3)$ & $205(27.3)$ \\
\hline $\begin{array}{l}\text { Phobia from going alone to bed at night } \\
n=658\end{array}$ & $431(65.5)$ & $227(34.5)$ & $418(63.5)$ & $240(36.5)$ & $293(44.5)$ & $365(55.5)$ & $138(21.0)$ & $142(21.6)$ & $208(31.6)$ & $170(25.8)$ \\
\hline $\begin{array}{l}\text { Feeling shudder when he is in darkness } \\
n=984\end{array}$ & $562(57.1)$ & $422(42.9)$ & $627(63.7)$ & $357(36.3)$ & $442(44.9)$ & $542(55.1)$ & $211(21.4)$ & $207(21.0)$ & $304(30.9)$ & $262(26.6)$ \\
\hline $\begin{array}{l}\text { Imagine in darkness that somebody on the } \\
\text { wall } n=930\end{array}$ & $543(58.4)$ & $387(41.6)$ & $635(68.3)$ & $295(31.7)$ & $402(43.2)$ & $528(56.8)$ & $245(26.3)$ & $179(19.2)$ & $283(30.4)$ & $223(24.0)$ \\
\hline Phobia from sitting in dark room $n=1044$ & $662(63.4)$ & $382(36.6)$ & $657(62.9)$ & $387(37.1)$ & $458(43.9)$ & $586(56.1)$ & $225(21.6)$ & $227(21.7)$ & $329(31.5)$ & $263(25.2)$ \\
\hline $\begin{array}{l}\text { Phobia from going bathroom when it is } \\
\text { dark } n=1151\end{array}$ & $677(58.8)$ & $474(41.2)$ & $727(63.2)$ & $424(36.8)$ & $546(47.4)$ & $605(52.6)$ & $252(21.9)$ & $214(18.6)$ & $353(30.7)$ & $332(28.8)$ \\
\hline p-valu & $<0.00$ & & 0.04 & & 0.02 & & 0.15 & & & \\
\hline $\begin{array}{l}\text { Feeling dizzy and shudder when he sees a } \\
\text { dog or cat } n=572\end{array}$ & $368(64.3)$ & $204(35.7)$ & $340(59.4)$ & $232(40.6)$ & $251(43.9)$ & $321(56.1)$ & $93(16.3)$ & $136(23.8)$ & $205(35.8)$ & $138(24.1)$ \\
\hline $\begin{array}{l}\text { Runaway and be tachycardia when seeing } \\
\text { a dog or cat } \mathrm{N}=790\end{array}$ & $498(63.0)$ & $292(37.0)$ & $462(58.5)$ & $328(41.5)$ & $311(39.4)$ & $479(60.6)$ & $174(22.0)$ & $159(20.1)$ & $250(31.6)$ & $207(26.2)$ \\
\hline $\begin{array}{l}\text { Phobia from rats and be tachycardia on } \\
\text { seeing a rat } n=1031\end{array}$ & 690 (66.9) & 341 (33.1) & $601(58.3)$ & $430(41.7)$ & $368(35.7)$ & $663(64.3)$ & $214(20.8)$ & $256(24.8)$ & $301(29.2)$ & $260(25.2)$ \\
\hline $\begin{array}{l}\text { Phobia from snacks even if he saw them } \\
\text { in TV or pictures } n=893\end{array}$ & $541(60.6)$ & $352(39.4)$ & $636(71.2)$ & $257(28.8)$ & $388(43.4)$ & $505(56.6)$ & 169 (18.9) & $183(20.5)$ & $298(33.4)$ & $243(27.2)$ \\
\hline $\mathrm{p}$-value & 0.035 & & $<0.001$ & & 0.00 & & 0.017 & & & \\
\hline $\begin{array}{l}\text { Phobia from untreatable illness (like } \\
\text { corona) } n=890\end{array}$ & $564(63.4)$ & $326(36.7)$ & $630(70.8)$ & $260(29.2)$ & $392(44.0)$ & $498(56.0)$ & $246(27.6)$ & $240(27.0)$ & $176(19.8)$ & $228(25.6)$ \\
\hline $\begin{array}{l}\text { Phobia from cockroach and become } \\
\text { tachycardia on viewing a cockroach } n=690\end{array}$ & $473(68.6)$ & 217 (31.4) & $458(66.4)$ & 232 (33.6) & $215(31.2)$ & $475(68.8)$ & $181(26.2)$ & $157(22.8)$ & $190(27.5)$ & $162(23.5)$ \\
\hline Phobia & & 484 & & & & & & & & $244(23.6)$ \\
\hline $\begin{array}{l}\text { Feeling that he will fall down while he is in } \\
\text { high places } n=1340\end{array}$ & $748(55.8)$ & $592(44.2)$ & 856 (63.9) & $484(36.1)$ & $568(42.4)$ & 772 (57.6) & $290(21.6)$ & $276(20.6)$ & $431(32.2)$ & $343(25.6)$ \\
\hline$p$-value & 0.2 & & 0.2 & & & & 0.0 & & & \\
\hline $\begin{array}{l}\text { Phobia fr } \\
\text { knows th }\end{array}$ & 30 & $209(40.7)$ & $372(7$ & $142(27.6)$ & 238 & $276(53.7)$ & $126(24.5)$ & $1.8)$ & $154(30.0)$ & $122(23.7)$ \\
\hline $\begin{array}{l}\text { Phobia when entering place where people } \\
\text { are gathered and talking } n=390\end{array}$ & $242(62.0)$ & $148(38.0)$ & $286(73.3)$ & $104(26.7)$ & $196(50.3)$ & $194(49.7)$ & $92(23.6)$ & $90(23.1)$ & $118(30.3)$ & $90(23.1)$ \\
\hline$p$-value & 0.449 & & 0.806 & & 0.267 & & 0.962 & & & \\
\hline
\end{tabular}

Table 4: Logistic regression of factors affecting phobia

\begin{tabular}{|c|c|c|c|c|c|}
\hline \multirow{2}{*}{ Variables } & \multirow[t]{2}{*}{ B } & \multirow[t]{2}{*}{$\mathrm{p}$} & \multirow[t]{2}{*}{ OR } & \multicolumn{2}{|c|}{$95 \% \mathrm{Cl}$ of $\mathrm{OR}$} \\
\hline & & & & Lower & Upper \\
\hline \multicolumn{6}{|l|}{ Low versus high } \\
\hline Type of school* & -0.485 & $<0.001$ & 0.615 & 0.501 & 0.757 \\
\hline Residence* & 0.321 & 0.003 & 1.379 & 1.115 & 1.706 \\
\hline Gender* & -1.478 & $<0.001$ & 0.228 & 0.186 & 0.279 \\
\hline School level/grade & 0.076 & 0.106 & 1.079 & 0.984 & 1.183 \\
\hline \multicolumn{6}{|l|}{ No versus low } \\
\hline Type of school* & -0.798 & 0.006 & 0.450 & 0.255 & 0.796 \\
\hline Residence* & 1.423 & $<0.001$ & 4.148 & 2.525 & 6.816 \\
\hline Gender* & -1.458 & $<0.001$ & 0.233 & 0.117 & 0.462 \\
\hline School level/grade & 0.209 & 0.070 & 1.232 & 0.983 & 1.545 \\
\hline \multicolumn{6}{|l|}{ No versus high } \\
\hline Type of school* & -1.389 & $<0.001$ & 0.249 & 0.130 & 0.479 \\
\hline Residence* $^{*}$ & 1.388 & $<0.001$ & 4.005 & 2.297 & 6.985 \\
\hline Gender* & -2.816 & $<0.001$ & 0.060 & 0.030 & 0.120 \\
\hline School level/grade & 0.118 & 0.396 & 1.125 & 0.857 & 1.476 \\
\hline
\end{tabular}

quality of life and disability in young populations. Thus, early diagnosis may help in the prevention of severe psychiatric symptoms [5], [23], [25].

Therefore, the present study discussed two major observations: First, identify the prevalence of most common phobias in the studied Egyptian primary schoolchildren, and second, determine the prevalence of different types of phobia according to certain characteristics. Most importantly, determine the influence of phobia from diseases on the occurrence of $\mathrm{PD}$ due to the corona pandemic.

Phobia consists of many types as a specific phobia (e.g., fear from darkness, animal, insect, or heights), agoraphobia (e.g., fear of crowded or narrow places), as well as, social phobia (as phobia when entering a place where people are gathered and talking for fear of embarrassing yourself and being humiliated in public), and medical phobia (afraid of illness). The results suggest that the most commonly reported phobias among the studied Egyptian schoolchildren were certain types of specific phobia (falling down from high places, phobia from dark places, and phobia from going bathroom when it is dark). Our study is aligned with others showing that the specific phobias were more common in children versus adults and adolescents, making it the most common anxiety disorder and one of the most common psychiatric disorders among children [25], [26]. This is explained by many stressors as parental overprotectiveness, physical abuse, parental separation or loss, death of a close relative, physical health, genetic vulnerability, etc. [26]. In contrast, social phobia was found to be more common among children by other studies [5], [27], [28], [29], [30]. Certain risk factors causing increase prevalence of social phobia as environmental and biological changes, family type, physical activity, meditation, etc. [5], [29].

The present study demonstrated that more than $5 \%$ of the studied schoolchildren had more than 5 types of phobia. This finding is supported by a study done by de Vries et al., 2019, who found that $8 \%$ of children reported four or more phobias [31]. The present 
study also scored the phobia into the low score (1-9) and high score $(\geq 10)$ which accounted for $60.9 \%$ and $35.2 \%$, respectively, of the studied participants. In this respect, the study carried out by Archana et al., 2017, described that mild and severe phobia accounted for $24.1 \%$ and $1.6 \%$, respectively [29]. Different levels of phobia may be due to the underlying influence of paternal and maternal factors on child development starting early after childbirth [32], [33], [34].

Gender differences in different phobias were explored in the current study which clarified that the different types of phobia were more prevalent in males than females with a significant difference. This is because boys are more susceptible to stress and neuropsychiatric disorders, so they need more care and support from their mothers [35] and maybe due to the way of the child-rearing with overprotectiveness of boys than girls especially in Egyptian rural communities which were more in this study. Moreover, the phobia was increased in rural areas than urban areas with a significant difference because of firm social controls by these communities [36]. However, other studies who were inconsistent with the current study finding and reported that phobias were more prevalent in female students than in males [5], [25], [27], [37], [38]. In addition, the problem of phobia is varying in rural and urban populations based on multiple issues [29].

Most of the phobias generally appear in early childhood, the studied fifth or sixth graders (9-12 years) showed the highest percentage for almost all types of phobia because older children are more susceptible to phobia than younger children. With respect to phobias, our results are in agreement with Bener et al., 2011; Varughese and Peteru, 2019; and de Vries et al., 2019 suggesting that phobias were common in the age group 6-11 years [5], [26], [31]. Results of other studies were somewhat different from those found in our sample, two studies suggested that the average age of onset of phobias symptoms at approximately 8 years [11], [37]. While one study found that the onset of phobias symptoms was more in the age group of 11-13 years [29]. This variation may be due to different socioenvironmental stresses.

Because phobia can spread quickly, so it has played an important role in coronavirus spread and the fear of catching the virus expressed by panic, stress, unhappiness, avoiding public places, psychosomatic diseases, etc. The most important thing that we have to fear is fear itself [39], [40], [41], [42]. Regarding PD due to the corona pandemic, the study reported $44.2 \%$ prevalence which could be considered as the highest prevalence worldwide. PD is likely to be increased with increased number of infected persons with coronavirus and number of deaths and expected to reach almost all people $(80 \%$ or $90 \%)$ if it is surveyed at this time. The highest PD symptoms were fear of losing any of the family members, especially grandparents (97\%), fear of the unknown consequences of the corona (78\%), and fear of dying because it has not a treatment yet (68\%).
The observed somatic complaints such as shortness of breath of children, chest pain, palpitations, nausea, trembling, sweating, and choking often misdiagnosed as anxiety or mood disorders. Such diagnosis often masks the presence of PD in primary schoolchildren. The majority of Egyptian studies among primary schoolaged groups seldom considered PD for such symptoms or studied its effect on cognitive and psychosocial development [42], [43], [44], [45], [46], [47]. These somatic symptoms were slightly higher in this study due to fear from corona and its complications more than symptoms caused by the disease itself.

Furthermore, our results indicate that the studied male schoolchildren, urban areas, and governmental schools were highly significant predicting factors for phobia regarding low score of phobia versus high score of phobia, no phobia versus high scores of phobia, and no phobia versus low scores of phobia, $p<0.001$.

It was notable that even with the high percentages of different types of phobia and with PD, no child who was diagnosed or had been referred to seek advice, further evaluation or treatment, indicating a very low level of awareness. It is really recommended to encourage community-based awareness programs to raise awareness of parents about phobia and how to manage. Such programs in Egypt are proved to be effective in many health settings resulted in the empowerment of the communities and in mitigation of many health problems [48], [49], [50], [51], [52], [53], [54].

\section{Strengths of the study}

Up to date, the majority of studies for phobia and PD has both small sample size and was done in a clinical setting such as hospitals or clinics. Our study is characterized by being a community based one. It is the first one in Egypt to study common and specific phobia as well as a PD due to the corona pandemic among primary school-aged children with a very large sample size (2015 children), with a high confidence level of $97 \%$ and low two-sided margin of error (0.05).

\section{Limitation of the study}

As this study was limited to investigate different forms of specific phobia without studying the symptoms of the specific phobia and without studying the sociodemographic implication. Moreover, self-reported symptoms of being panic due to the corona pandemic were the focus of the study without studying the comorbidity between PD and internalizing and externalizing disorders. Another limitation is that children were assessed by a self-reported questionnaire rather than with the use of structured diagnostic interviews that tend to be lengthy. Meanwhile, the cognitive capabilities of school-aged children are below what is required to fill in these questionnaires. Although 
the role of the paternal and maternal parameters on child development is well evident in many Egyptian studies [32], [33], [34] starting early after childbirth, yet the current study also obscured exploring such influence as underlying factors for the variation of the widespread of specific phobia.

\section{Conclusion and Recommendation}

Although our sample is not representative of the whole Egyptian schoolchildren, yet it represents the opinion of primary schoolchildren of different geographical and socioeconomic levels. Phobia from heights and darkness was the most common with a higher frequency in the 9-12 years old age group (fifth or sixth graders). Boys had higher rates of all phobic disorders than girls. The important determinants of phobias were the type of school, residence, gender, and school-level/grade.

The prevalence of PD due to the corona epidemic is very high, it is reported by almost half of the surveyed primary schoolchildren. Fear of losing any of their family members, especially grandparents, fear of the unknown consequences of the corona, and fear of death were reported to be the highest PD symptoms. The prevalence of PD due to the coronavirus epidemic is reported to be very high.

It is important to assure fearful children and their parents that during lockdown, they should be optimistic. They should know that mental and spiritual wellbeing are linked and important during the crisis to decrease their suitability to diseases. To enable parents to work optimally from home, it is necessary to create an enabling environment that is free from any phobia or panic. This is also necessitated to calm down children who might be experienced with a phobia that is triggering their PD.

We believe our responsibility lies in catalyzing the process of helping people seamlessly to be engaged and motivated on ways to make their work from home "business as usual" safe, smart, and swift. This will be achieved by assuring their children and reducing their PDs.

\section{Ethics Approval and Consent to Participate}

The study complied with the International Ethical Guidelines for Biomedical Research Involving Human Subjects. Written consent was obtained from parents of all participants after ensuring their full understanding of the research. Information obtained at the individual level was kept strictly confidential.

Approval of the Ministry of Education before starting the research was taken. The study ethical approval was obtained from the Medical Research Ethics Committee of the National Research Centre with the ethical approval number of 19068 .

\section{Acknowledgments}

The authors express their thanks and appreciation to the studied schoolchildren and their parents for their willingness to participate and cooperate during the implementation of the study.

\section{Authors' Contributions}

AMM and HE conceived and designed the study. MME, EE, and $A E$ conducted field visits and data collection. AMM, HE GAA, and NAI oversaw the implementation. GAA did the statistical analyses and interpreted the data. GAA and MME drafted the paper. AMM and LE reviewed the manuscript. GAA submitted the manuscript. All authors provided input into the manuscript and approved the final version.

\section{Availability of Data and Materials}

The datasets used and/or analyzed during the current study are available from the corresponding author on reasonable request.

\section{References}

1. NHS. Overview Phobias. Available from: https://www.nhs.uk/ conditions/phobias. [Last accessed on 2020 Feb 18]

2. Children's Hospital of Philadelphia. Phobias in Children and Adolescents; 2020. Available from: https://www.chop.edu/ conditions-diseases/phobias-children-and-adolescents. [Last accessed on 2020 Mar 23].

3. Lydon S, Healy O, O'Callaghan O, Mulhern T, Holloway J. A systematic review of the treatment of fears and phobias among children with autism spectrum disorders. Rev J Autism Dev Disord. 2015;2:141-54. https://doi.org/10.1007/ s40489-014-0043-4

4. Watson LR, Fraser M, Ballas P. Phobias in Children. University of Rochester Medical Center Rochester; 2020. Available 
from: https://www.urmc.rochester.edu/encyclopedia/content. aspx?contenttypeid=90\&contentid=P01639. [Last accessed on 2020 Mar 23].

5. Bener A, Ghuloum S, Dafeeah EE. Prevalence of common phobias and their socio-demographic correlates in children and adolescents in a traditional developing society. Afr J Psychiatry (Johannesbg). 2011;14(2):140-5. https://doi.org/10.4314/ajpsy. v14i2.6

\section{PMid:21687913}

6. Nielsen MD, Andreasen CL, Thastum M. A Danish study of one-session treatment for specific phobias in children and adolescents. Scand J Child Adolesc Psychiatry Psychol. 2016;4(2):65-76. https://doi.org/10.21307/sjcapp-2016-011

7. Eaton WW, Bienvenu J, Miloyan B. Specific phobias. Lancet Psychiatry. 2018;5:678-86. https://doi.org/10.1016/ s2215-0366(18)30169-x

PMid: 30060873

8. Oar EL, Farrell LJ, Ollendick TH. Pediatric Anxiety Disorders. In: Specific Phobia. Ch. 7. Cambridge, Massachusetts: Academic Press; 2019. p. 127-50. https://doi.org/10.1016/ b978-0-12-813004-9.00007-4

9. Fehma L, Pelissolo A, Furmark T, Wittchen H. Size and burden of social phobia in Europe. Eur Neuropsychopharmacol. 2005;15:453-62. https://doi.org/10.1016/j.euroneuro.2005.04.002 PMid: 15921898

10. George CM. Solution-focused therapy: Strength-based counseling for children with social phobia. J Humanist Couns Educ Dev 2008;47:144.

11. Yates WR, Munir KM. Pediatric Specific Phobia. Drugs and Diseases Pediatrics: Developmental and Behavioral Articles. Medscape; 2018. Available from: https://wwwemedicine. medscape.com/article/917056-overview. [Last accessed on 2018 Aug 09].

12. Ollendick TH. Panic disorder in children and adolescents: New developments, new directions. J Clin Child Psychol. 1998;27(3):234-45.

PMid:9789184

13. Birmaher B, Ollendick TH. Childhood-onset panic disorder. In: Ollendick TH, March JS editors. Phobic and Anxiety Disorders in Children and Adolescents. New York: Oxford University Press; 2004. p. 306-33. https://doi.org/10.1093/ med: psych/9780195135947.003.0011

14. Leonard AD, Daniel FC, Adam MV, Peter FT. Panic disorder in clinically referred children and adolescents. Child Psychiatry Hum Dev. 2007;38:57-71. https://doi.org/10.1007/ s10578-006-0042-5

15. Goodman B. Know the Symptoms of COVID-19. WebMD Health News. Available from: https://www.webmd.com/lung/ news $/ 20200310 /$ know-the-symptoms-of-covid19?ecd=wnl_ gdh_032120\&ctr=wnl-gdh-032120_nsl-LeadModule cta \&mb $=\% 2 \mathrm{f} 12 \mathrm{pfMMr} 1 \mathrm{Tq} 6 \mathrm{ELQOtS} 4 \mathrm{z} 1 \mathrm{uHnVev} 1 \mathrm{imb}$ CveYL4\%2fXv82Y\%3d. [Last accessed on 2020 Mar 10].

16. WebMD News Staff. Coronavirus 2020 Outbreak: Latest Updates. WebMD Health News. Available from: https://www. webmd.com/lung/news/20200124/coronavirus-2020-outbreaklatest-updates?ecd=wnl_spr_032220\&ctr=wnl-spr-032220 nslLeadModule_cta\&mb=\%2f12pfMMr1Tq6ELQOtS4z1uHnV ev1imbCveYL4\%2fX v82Y\%3d. [Last accessed on 2020 Mar 25]. https://doi.org/10.2174/1568026620999200305144537

17. Cleveland Clinic. What Happens When Your Immune System Gets Stressed Out? How Stress Impacts your Immunity and how to Chill Out. Health Essentials. Rheumatology and Immunology. Available from: https://www.health.clevelandclinic. org/what-happens-when-your-immune-system-getsstressed-out. [Last accessed on 2017 Mar 01]. https://doi. org/10.4135/9781452229324.n2
18. Neal B. Can Stress Cause Physical Illness? This is how Anxiety Affects your Immune System. Available from: https://www. bustle.com/p/can-stress-cause-physical-illness-this-is-howanxiety-affects-your-immune-system-7524590. [Last accessed on 2017 Dec 09].

19. Cherney K. Immune System. Effects of Anxiety on the Body. Healthline Media. Available from: https://www.healthline. com/health/anxiety/effects-on-body\#7. [Last accessed on 2018 Jul 20].

20. Fleiss JL, Levin B, Paik MC. Statistical Methods for Rates and Proportions. $3^{\text {rd }}$ ed. New York: John Wiley and Sons; 2003.

21. American Psychiatric Association. Diagnostic and Statistical Manual of Mental Disorders. $4^{\text {th }}$ ed. Washington, DC: American Psychiatric Association; 2000.

22. Khan Academy. Z-statistics vs. T-statistics; 2018. Available from: Available from: https://www.khanacademy.org/math/ statistics-probability/significance-tests-one-sample/moresignificance-testing-videos/v/z-statistics-vs-t-statistics. https:// doi.org/10.1016/0167-7152(84)90068-3. [Last accessed on 2020 Mar 15].

23. de Menezes S, Vance A. Social phobia in children risk and resilience factors. Aust Med Stud J. 2014;4(2):66-69

24. Laporte PP, Pan PM, Hoffmann MS, Wakschlag LS, Rohde LA, Miguel EC, et al. Specific and social fears in children and adolescents: Separating normative fears from problem indicators and phobias. Rev Bras Psiquiatria. 2017;39(2):11825. https://doi.org/10.1590/1516-4446-2016-2064 PMid:28300935

25. Pitts $\mathrm{CH}$, Klein-Tasman BP, Osborne JW, Mervis CB. Predictors of specific phobia in children with Williams syndrome. J Intellect Disabil Res. 2016;60(10):1031-42. https://doi.org/10.1111/jir.12327 PMid:27545817

26. Varughese A, Peteru S. Specific phobia vs panic disorder in children: A unique case report and review of literature. J Depress Anxiety. 2019;8(1):327.

27. Sanna K, Rachel PW, Hanna E, Hurtig T, Joskitt L, Mattila ML, et al. Psychometric evaluation of social phobia and anxiety inventory for children (SPAI-C) and social anxiety scale for children-revised (SASC-R). Eur Child Adolesc Psychiatry. 2009;18(2):116-24. https://doi.org/10.1007/s00787-008-0712-x PMid: 18807111

28. Tulbure BT, Szentagotai A, Dobrean A, David D. Evidence based clinical assessment of child and adolescent social phobia: A critical review of rating scales. Child Psychiatry Hum Dev 2012;43(5):795-820. https://doi.org/10.1007/ s10578-012-0297-y

PMid:22438106

29. Archana S, Prasad K N, Jabeen B. Prevalence of social anxiety disorder and its determinants in school going adolescents in rural population of Ramnagara district. Int $\mathrm{J}$ Med Sci Public Health. 2017;6(8):1308-13. https://doi.org/10.5455/ ijmsph.2017.0513413062017

30. Mohammadi MR, Salehi M, Khaleghi A, Hooshyari Z, Ali Mostafavi S, Ahmadi N, et al. Social anxiety disorder among children and adolescents: A nationwide survey of prevalence, socio-demographic characteristics, risk factors and co-morbidities. J Affect Disord. 2020;263:450-7. https://doi. org/10.1016/j.jad.2019.12.015

PMid:31969277

31. de Vries YA, Al-Hamzawi A, Alonso J, Borges G, Bruffaerts R, Bunting $B$, et al. Childhood generalized specific phobia as an early marker of internalizing psychopathology across the lifespan: Results from the World Mental Health Surveys. BMC Med. 2019;17(1):101. https://doi.org/10.1186/s12916-019-1328-3 PMid:31122269

32. Metwally AM, Salah El-Din EM, Shehata MA, Shaalan A, E 
Etreby LA, Kandeel WA, et al. Early life predictors of socioemotional development in a sample of Egyptian infants. PLoS One. 2016;11(7):e0158086. https://doi.org/10.1371/journal. pone. 0158086

33. Kandeel WA, Rabah TM, Zeid DA, El-Din EMS, Metwally AM, Shaalan $A$, et al. Determinants of exclusive breastfeeding in a sample of Egyptian infants. Open Access Maced J Med Sci. 2018;6(10):1818-23. https://doi.org/10.3889/oamjms.2018.359 PMid:30455755

34. El Din EM, Rabah TM, Metwally AM, Nassar MS, Elabd MA, Shaalan $A$, et al. Potential risk factors of developmental cognitive delay in the first two years of life. Open Access Maced J Med Sci. 2019;7:2024-30. https://doi.org/10.3889/oamjms.2019.566 PMid:31406549

35. Narvaez DF. Be Worried About Boys, Especially Baby Boys. Allan Schore Discusses the Harmful Effects of Stressing Baby Boys. Available from: https://www.psychologytoday.com/ us/blog/moral-landscapes/201701/be-worried-about-boysespecially-baby-boys. [Last accessed on 2017 Jan 08]. https:// doi.org/10.3138/9781442662438-006

36. Peen J, Schoevers R, Beekman AT, Dekker J. The current status of urban rural differences in psychiatric disorders. Acta Psychiatr Scand. 2009;121(2):84-93. https://doi. org/10.1111/j.1600-0447.2009.01438.x PMid:19624573

37. Ahmed ZA, Abed El-Kader NM, Essa MA, Mohamed II. Impact of a specialized interaction program on behavioral modification of specific phobias among primary school students. Asian Acad Manag J. 2010;8:150-164.

38. Hitchcock CA, Chavira DA, Stein MB. Recent findings in social phobia among children and adolescents. Isr J Psychiatry Relat Sci. 2009;46(1):34-44.

PMid: 19728571

39. Kycheng K. Coronavirus: How Media Coverage of Epidemics Often Stokes Fear and Panic. United Kingdom: The Conversation Africa, Inc. Available from: https://www.theconversation.com/ coronavirus-how-media-coverage-of-epidemics-often-stokesfear-and-panic-131844. [Last accessed on 2020 Feb 14].

40. Kumar M. Curing the Corona Fear. Available from: https://www. telanganatoday.com/curing-the-corona-fear. [Last accessed on 2020 Mar 09].

41. Coronaphobia. Urban Dictionary. Available from: https://www. urbandictionary.com/define.php?term=coronaphobia. [Last accessed on 2020 Mar 07].

42. Metwally AM, El-Sonbaty MM, El Etreby LA, Salah El-Din EM, Abdel Hamid N, Hussien HA, et al. Impact of National Egyptian school feeding program on growth, development, and school achievement of school children. World J Pediatr 2020. (In press). https://doi.org/10.1007/s12519-020-00342-8

43. El-Din EM, Elabd MA, Nassar MS, Metwally AM, Abdellatif GA, Rabah TM, et al. The interaction of social, physical and nutritive factors in triggering early developmental language delay in a sample of Egyptian children. 2019;7(17):2767-2774. https://doi. org/10.3889/oamjms.2019.642

PMid:31844434
44. Salah EM, Khalifa AG, Metwally AM, Hamid NA, Hussien HA, Moneer ZM. The impact of school snacks on cognitive function of primary school children in Egypt. J Appl Sci Res. 2012;8(12):5639-50.

45. Boraey NF, El-Sonbaty MM. Behavioral problems in children with nephrotic syndrome. J Appl Sci Res. 2011;7(12):2001-7.

46. Salem S, Salah H, El-Sonbaty MM, Fathy A. The impact of chronic chest trouble on cognitive functions, psychosocial behavior and academic achievement among Egyptian children. J Appl Sci Res. 2012;8(7):3459-68.

47. El-Sonbaty MM, Fathy A, Aljohani A, Fathy A. Assessment of behavioural disorders in children with functional constipation. Open Access Maced J Med Sci. 2019;7(23):4019-22. https:// doi.org/10.3889/oamjms.2019.677 PMid:32165945

48. Metwally AM, Saleh RM, El-Etreby LA, Salama SI, Aboulghate A, Amer HA, et al. Enhancing the value of women's reproductive rights through community based interventions in upper Egypt governorates: A randomized interventional study. Int J Equity Health 2019;18(1):146. https://doi.org/10.1186/ s12939-019-1042-y

49. Metwally AM, Soliman M, Abdelmohsen AM, Kandeel WA Saber M, Elmosalami DM, et al. Effect of counteracting lifestyle barriers through health education in Egyptian Type 2 diabetic patients. Open Access Maced J Med Sci. 2019;7(17):2886-94. https://doi.org/10.3889/oamjms.2019.624 PMid:31844454

50. Shiha G, Metwally AM, Soliman R, Elbasiony M, Mikhail NN, Easterbrook P. An educate, test, and treat programme to reduce hepatitis $\mathrm{C}$ in Egypt: Results from a communitybased demonstration project. Lancet Gastroenterol Hepatol. 2018;3(11):778-89. https://doi.org/10.1016/ s2468-1253(18)30139-0 PMid:30030068

51. Salama II, Sami SM, Said ZN, Salama SI, Rabah TM, AbdelLatif GA, et al. Early and long term anamnestic response to HBV booster dose among fully vaccinated Egyptian children during infancy. Vaccine. 2018;36(15):2005-11. https://doi. org/10.1016/j.vaccine.2018.02.103 PMid:29530634

52. Salama II, Sami SM, Said ZN, El-Sayed MH, El-Etreby LA, Rabah TM, et al. Effectiveness of hepatitis $B$ virus vaccination program in Egypt: Multicenter national project. World J Hepatol. 2015;7(22):2418-26. https://doi.org/10.4254/wjh.v7.i22.2418 PMid:26464758

53. Metwally AM, Saad A, Ibrahim NA, Emam HM, El-Etreby LA Monitoring progress of the role of integration of environmental health education with water and sanitation services in changing community behaviours. Int J Environ Health Res. 2007;17(1): 61-74. https://doi.org/10.1080/09603120600937856

54. Metwally AM, Ibrahim NA, Saad A, Abu El-Ela M. Improving rural women role in health and environmental issues. Int J Environ Health Res. 2006;16(2):133-44. https://doi. org/10.1080/09603120500539208

PMid: 16546806 